\title{
Title: The dispersion of crime concentration during a period of crime increase
}

Corresponding author: Spencer P. Chainey. Department of Security and Crime Science, University College London, 35 Tavistock Square, London, England. s.chainey@ucl.ac.uk Joana Monteiro. Instituto de Segurança Pública, Avenida Presidente Vargas, 817 - 16, Rio de Janeiro, Brazil. joanacmm@gmail.com

Published 2019

Security Journal DOI https://doi.org/10.1057/s41284-019-00165-x

\begin{abstract}
Extensive empirical evidence shows that crime concentrates in place, with these findings being important for helping to target police resources. Little is known, however, about whether these crime concentration areas are where crime increases the most during a period of crime increase. Using data from the seven largest cities in the state of Rio de Janeiro, Brazil, we show that during a period of crime increase the locations most responsible for the increases were the micro-places where crime previously concentrated. We argue that the increases in crime in areas of crime concentration were mainly due to these places offering stable favourable conditions for crime. The study introduces a simple index - the Crime Concentration Dispersion Index - that helps police agencies determine where to target resources during a period of crime increase and offers results that provide an important Latin American urban perspective to the literature on crime concentration.
\end{abstract}

Key words: crime concentration, hot spot policing, crime stability, robbery, Latin America

\section{Introduction}


The notion that crime concentrates in places is a well-established observation in geographical studies of crime, to the extent that Weisburd (2015) has suggested a law of crime concentration. Weisburd's (2015) law of crime concentration focusses attention to the micro-place scale (such as street segments) rather than coarser geographic administrative areas (e.g., census blocks) or identifying crime hot spots using interpolation techniques (e.g., kernel density estimation). At the micro-place level of analysis, crime concentrates at significant levels, relative to the distribution of crime across all micro-place units (Sherman et al., 1989; Weisburd, 2015; Lee et al., 2017). Crime concentration is also seen to be highly stable over time (Gill et al., 2017; Weisburd et al. 2004). The observation that crime highly concentrates in space and that these patterns tend to persist has in turn presented opportunities for countering these patterns. Most notably, hot spot policing, involving the targeting of police patrols to the areas where high concentrations of crime have been observed, has had a demonstrable effect in reducing crime (Braga et al, 2012).

To date, research that has examined the concentration of crime at the micro-place level and the stability of these patterns has mainly been confined to a number of US-based studies. Little has been published that examines the concentration of crime in Latin American cities, and in particular for robbery (e.g., Lee et al's, 2017 systematic review of the crime concentration literature included no studies from Latin America). This article reports on an examination of the concentration of robbery for seven cities in the state of Rio de Janeiro, Brazil. The results provide a useful comparison to western industrialized countries by illustrating the very high degree of robbery concentration in each of the study areas. Rio de Janeiro, similar to many Latin American cities, has robbery levels that are far higher than western industrialized cities, and has recently experienced increases in this type of crime. In this article, we build on existing research on crime concentration by identifying whether, 
during a period of crime increase, the locations most responsible for the increases are the micro-places where crime concentrates. In-so-doing we introduce a crime concentration dispersion measure to determine if hot spots have just become hotter, or if other areas are responsible for the crime increase. Our results suggest that hot spot policing, which has received little attention in Latin American cities (Jaitman and Ajzenman, 2016), could offer similar crime reduction benefits in cities such as Rio de Janeiro. We show that not only are robbery patterns highly concentrated, but that additionally, even during a period of significant crime increase, targeting these high crime concentration areas potentially provides the best opportunity for reducing crime levels.

Section 2 of the paper describes the main observations relating to the spatial concentration of crime and measures for examining the stability of crime patterns during a period of crime increase. In section 3 the data and methods are described, and includes introducing the Crime Concentration Dispersion Index as a measure for determining if areas where crime concentrates are the areas mainly associated with an increase in crime. In section 4 the results are presented, in section 5 we discuss the results and provide conclusions in section 6.

\section{The law of crime concentration and measures of spatial crime stability}

Research on the criminology of place has become increasingly concerned with examining crime at the micro-place level. Since the first studies into the geography of crime in the 1800s (Guerry, 1833), the geographic unit of study has grown ever finer. In part, this has followed from continual improvements in the spatial level at which crime data has been recorded, but also reflects a growing recognition that city, sub-city and neighborhood level analysis hides much of the spatial heterogeneity that is apparent in criminal activity (Andresen and Malleson, 2011; Weisburd et al., 2009). 
Since the 1980 's, numerous studies have found that crime significantly concentrates at small geographic scales (for a full review see Lee et al., 2017). This has led Weisburd (2015) to propose a law of crime concentration, oriented to micro-places, that states that crime concentrates within a tight spatial bandwidth. Weisburd's notion of a micro-place is the street segment, a behavioral activity setting that is present in all landscapes, and typically precise in its spatial coverage. Weisburd's examination of crime concentration resulted in defining the bandwidths of percentages within which crime concentration will fall, for two cumulative proportions of crime: for a cumulative proportion of 25 per cent of crime, the bandwidth for the proportion of micro-places is between 0.4 and 1.6 per cent; and for a cumulative proportion of 50 per cent of crime, the bandwidth for the proportion of microplaces is between 2.1 and 6 percent.

The tight spatial bandwidths within which crime is predicted to concentrate were also stated by Weisburd (2015) as being applicable across all types of crime and for different settings. Crime in Latin American cities provides a useful difference in setting to examine the applicability of the law of crime concentration, particularly when the region continues to experience high levels of violent crime (Inter-American Development Bank, 2016). The robbery of a person's possessions while they are on a street or other area of public space is a crime type of major concern in the Latin American region. This is because robbery is high in volume, is typically 5-10 times greater in most Latin American cities than in cities in North America and Europe (UNODC, 2017), and because of the influence that prior victimization of robbery has on influencing people's fear of crime and their trust in the police (Dammert and Malone, 2006). To date, only two peer reviewed studies have examined crime 
concentration in Latin America (de Melo et al., 2015; Pereira et al., 2016) ${ }^{1}$. Examining the concentration of robbery at micro-places in Latin American cities helps to further test the validity of Weisburd's (2015) law of crime concentration and the relevance of the bandwidths that have been proposed. Whilst Weisburd's bandwidths for crime concentration are rather simply defined to two sets of rounded values ${ }^{2}$, the current research follows Weisburd's method to optimize comparisons with other studies.

While examining crime concentration at the micro-place level can help indicate where to target initiatives such as hot spot policing patrols, of additional interest is whether, during a period of crime increase, the places where crime concentrates are responsible for the crime increase. Several longitudinal studies of the geography of crime have shown that patterns tend to be very stable (Groff et al, 2008; Weisburd et al, 2004; Weisburd et al, 2009) and the small proportion of areas where crime was observed to concentrate accounted for the majority of the crime reductions that were then experienced (Braga et al., 2010; Braga et al., 2011; Curman et al., 2014; Gill et al., 2017). To date, no known study has examined the stability of crime concentration at the micro-place level during a period of crime increase. For resource targeting purposes, knowing whether the areas where crime has increased are the areas where crime has previously concentrated or whether the crime increase is associated with other areas is important for informing prioritization strategies. Additionally, very little is known at present about why crime concentrates in some micro-places and not in others (Braga et al., 2017; Steenbeck and Weisburd, 2016; Weisburd, 2015; Weisburd and Telep, 2014). Our examination of the patterns of crime concentration during a period of

\footnotetext{
1 A study by the Inter-American Development Bank (Jaitman and Ajzenman, 2016) examined crime concentrations but only for all crime rather than any specific crime types. Another study by the Development Bank of Latin America examined patterns of crime concentration in Bogatá, Colombia (Mejia et al., 2015). ${ }^{2}$ Other crime concentration measures have been proposed (e.g., Bernasco and Steenbeek, 2017) but have received little application to date to allow for comparison.
} 
crime increase may help to contribute to the theoretical knowledge about why crime concentrates at the micro-place level.

Andresen (2009) proposed the use of a spatial point pattern test with a nonparametric Monte Carlo approach for measuring the degree to which one pattern of crime differs to another. Ratcliffe (2010) demonstrated the use of a crime increase dispersion method that can help identify those areas that are most responsible for an overall crime increase. Whilst Andresen's and Ratcliffe's measures are useful for examining the stability of crime patterns and observing where increases have mainly occurred, neither provides a direct means of determining if the crime increase is more associated with an increase in crime concentration areas (i.e., if hot spots have become hotter) or if the increase in crime is more associated with increases in other areas (i.e., new hot spots are responsible for the crime increase). To address this we introduce the Crime Concentration Dispersion Index and illustrate how this measure can help determine whether, during a period of crime increase, interventions should be targeted at areas of high crime concentration or if interventions should additionally consider other emerging hot spots.

The current study, therefore, has two primary objectives: to determine, within a Latin American urban context, whether the concentration of crime, specifically for robbery, fits within the bandwidths of crime concentration at places predicted by Weisburd (2015); and to determine if increases in crime are more associated with increases in crime concentration areas or increases in other areas.

\section{Method}


The research used recorded robbery data for the period 1 January 2015 to 31 December 2016 for the seven cities that have populations greater than 425,000 in the state of Rio de Janeiro, Brazil (see Figure 1) - Niteroi, Belford Roxo and São João de Meriti (with populations of approximately 500,000), Duque de Caxias, São Gonçalo and Nova Iguaçu (with populations between 800,000 and 1,000,000), and the city of Rio de Janeiro (with a population of 6,500,000). Table 1 lists the population density and the levels of robbery in each city in 2016. The state of Rio de Janeiro experienced a 40 per cent increase in robberies between 2015 and 2016, with five of the study areas experiencing increases that were greater than 60 per cent. These increases were not related to any changes in recording practice, nor were they related to any short-term increase in robbery during the 2016 Olympic Games. The increase in robberies began in 2014 and continued to gather pace during 2016. The geocoding hit rate for the robbery records was above the 85 per cent minimum threshold for reliability suggested by Ratcliffe (2004).

$<$ Figure 1 here>

<Table 1 here>

Street segments offer a sensible unifying micro-place unit for examining crime concentration (Smith et al., 2000; Weisburd et al, 2012), however, they can be problematic units of analysis to use in several situations. First, the use of street segments as a microplace unit assumes that all crime data can be geocoded to streets. In many non-US countries, crime is geocoded to address points and land parcels, referenced via land and property gazetteers (Chainey and Ratcliffe, 2005). While the joining of gazetteer referenced crime data to street segments is a technically possible, it assumes that street segment files exist. In 
many countries this is not the case. Secondly, street segments are of varying length. In Weisburd's (2015) analysis of crime concentration across the eight cities that were examined, the average length of street segments ranged from 183 feet to 681 feet. This means the varying length of street segments produce results that may not be directly comparable when reporting on crime concentration levels. Thirdly, in many cities where street segment data do exist, the crime record is geocoded to a street junction, creating issues in assigning incidents to an appropriate street segment. For example, in Weisburd's 2015 study up to a third of crime incidents were excluded from the analysis because these data were geographically referenced to street junctions, with their exclusion likely to have some impact on the results.

In several Latin American cities, such as Rio de Janeiro, street segment files do not exist, therefore, an alternative micro-place unit is required in order to geocode and examine crime concentration at these geographic scales (Mendes de Miranda and Ferreira, 2008). Microgrid cells offer a practical alternative to street segments because they are comparable to each other, can be constructed to be comparable to the geographic scale of other micro-place units (such as street segments), and are at lower risk to the modifiable areal unit problem (Openshaw, 1984) when they are small in size (Chainey et al., 2008). In Rio de Janeiro, authorities examine patterns of crime using $150 \mathrm{~m} * 150 \mathrm{~m}$ grid cells. These grid cells only cover built up areas, usable public space and the street network, rather than including mountains and forested areas. Grids cells of $150 \mathrm{~m} * 150 \mathrm{~m}$ are comparable (albeit slightly larger) to the average street segment length of 472 feet used by Weisburd (2015). Whilst grid cells may not naturally represent behavioral settings in the same way that street segments do, grid cells are an easier geographic unit to use when seeking to apply other 
spatial statistical tests that require the aggregation of data to geographical units. For each grid cell, the number of robberies in 2015 and 2016 were calculated, from which the number of grid cells representing 25 per cent and 50 per cent of all robbery in each year was determined.

Andresen's S Index (Andresen, 2009) is a spatial point pattern test that applies a nonparametric Monte Carlo approach for measuring the degree of similarity between two observations. The S Index varies between 0 and 1 . The closer the $S$ Index value is to 1 , the more similar (stable) the pattern. Andresen (2009) suggests that an index of 0.8 or higher indicates a stable spatial pattern. S Index values of robbery were calculated by comparing 2015 and 2016 data for each city ${ }^{3}$. Andresen's S Index test also identifies areas where the change in crime has been significant, and which in turn can be used to help inform police resource targeting. To identify these areas requires point data to be aggregated to small geographic units. Counts of crime in each $150 \mathrm{~m} * 150 \mathrm{~m}$ grid cell, derived from the original point data were used to perform these calculations. Following Andresen and Malleson's method (2011) 200 runs of the S Index were performed for each city to determine those cells that had experienced significant increases in crime $(\mathrm{p}=0.01)$. Cells where crime had significantly increased were compared to the cells that had been identified as areas that experienced the highest levels of crime concentration in 2016 (i.e., grid cells representing 25 per cent of all robbery).

\footnotetext{
${ }^{3}$ Andresen's S Index software is available here: http://www.sfu.ca/ andresen/spptest/spptest.html
} 
Whilst the $\mathrm{S}$ Index indicates if crime patterns between each year remained stable and identifies those areas where the increase in crime was statistically significant, Ratcliffe's dispersion indices (Ratcliffe, 2010), calculated using the Dispersion Calculator ${ }^{4}$, indicate if the overall crime increase is associated with only a small number of areas or if the increase is a spreading (emergent) problem. In so doing, the results generated by the Dispersion Calculator can help in police resource targeting. The geographic areal units used by the Dispersion Calculator are defined by the user, meaning that the grid cells used for previous tests could again be used for comparison. The Offence Dispersion Index (ODI, ranging from 0 to 1 ) determines the proportion of areas that alone have contributed to a study area-wide equivalent increase in crime. ODI values close to 0 indicate that crime has increased in only a small number of areas. The Non-Contributory Dispersion Index (NCDI, ranging from 0 to 1) indicates the proportion of other areas that are a concern. A NCDI close to 0 , especially in conjunction with a low ODI, suggests the increase in crime has occurred in only a small number of areas, whilst a value close to 1 indicates the crime increase has spread to other areas. ODI and NCDI values were calculated for each city. The Dispersion Calculator also identities the areas that alone have contributed to an equivalent increase in crime across the entire study region (from this point referred to as emerging problem areas - EPAs). Cells that were identified as EPAs were compared to the cells that had been identified as areas of high crime concentration and cells determined from the S Index as experiencing significant increases in crime.

The S Index, ODI and NCDI are useful measures for examining the stability of crime and the dispersion of crime increase, however, when a period of crime increase has been

\footnotetext{
${ }^{4}$ Ratcliffe's Dispersion Calculator software is available here: http://www.jratcliffe.net/software/dispersioncalculator/
} 
experienced these measures do not directly indicate if the areas where crime concentrates are the areas where resources should continue to be targeted. Whilst calculating the proportion of EPAs in comparison to the areas that were also high crime concentration areas is useful, this would not necessarily indicate if the main crime increase has been in the high crime concentration areas.

To address this shortcoming, the Crime Concentration Dispersion Index (CCDI) is introduced as a measure for determining if areas of high crime concentration are responsible for the crime increase. The CCDI is the ratio of the crime increase in EPAs that were not identified as high crime concentration areas between two time periods, $\mathrm{t} 1$ and $\mathrm{t} 2$, and the crime increase in high crime concentration areas between $\mathrm{t} 1$ and $\mathrm{t} 2$. This process required the Dispersion Calculator to initially determine those areas that were EPAs. The EPAs were then compared to the high crime concentration areas in $\mathrm{t} 2$ to determine those EPAs that were not identified as high crime concentration areas in $\mathrm{t} 2$ (referred to from this point forward as non-CC EPAs). For the non-CC EPAs, the total increase in crime experienced between $\mathrm{t} 1$ (i.e., 2015) and t2 (i.e., 2016) was calculated, and then averaged per non-CC EPA. Similarly, for the high crime concentration areas (CCAs), the total increase in crime experienced between $\mathrm{t} 1$ and $\mathrm{t} 2$ for all high crime concentration areas was calculated, and then averaged per high crime concentration area. The CCDI is the ratio between the increase in crime per non-CC EPA and the increase in crime per high crime concentration area. An example is provided below.

Crime Concentration Dispersion Index (CCDI) $=\frac{\text { Crime increase between } t 1 \text { and } t 2 \text { per non-CC EPA }}{\text { Crime increase between } t 1 \text { and } t 2 \text { per CCA }}$ 
Example:

Crime increase in whole study area (between $\mathrm{t} 1$ and $\mathrm{t} 2)=1,000$

n of geographic units in study area $=40,000$

$\mathrm{n}$ of geographic units that are high crime concentration areas (representing 25 per cent of all crime $)=400$

$\mathrm{n}$ of geographic units that are EPAs $=1550$

$\mathrm{n}$ of EPAs that are high crime concentration areas $=350$

$\mathrm{n}$ of non-CC EPAs $=1200$

Crime increase in high crime concentration areas (between $\mathrm{t} 1$ and $\mathrm{t} 2$ ) $=400$

Crime increase per high crime concentration area $(\mathrm{CCA})=1.0$

Crime increase in non-CC EPAs (between $\mathrm{t} 1$ and $\mathrm{t} 2)=400$

Crime increase per non-CC EPA $=0.33$

$\mathrm{CCDI}=0.33$ (i.e., $0.33 / 1.0)$

A CCDI less than 1 indicates that high crime concentration areas contributed more to the increase than other emerging problem areas (i.e., the non-CC EPAs). A CCDI of 1 indicates that high crime concentration areas and other EPAs equally contributed to the increase. The closer the CCDI is to 0 , the less the need for targeting resources to areas other than high crime concentration areas when a crime increase has been experienced (i.e., hot spots have become hotter). CCDI values close to 1 indicate that other areas are also responsible for the crime increase, suggesting that these new emerging areas also require attention if crime is to be reduced. A CCDI of greater than 1 indicates that other EPAs contributed more to the increase than high crime concentration areas.

\section{Results}


The level of crime concentration varied between each city, with Duque de Caxias and Nova Iguaçu experiencing the highest levels of robbery concentration (e.g., 25 per cent of robbery was concentrated in no more than 0.5 per cent of all micro-units), and Belford Roxo and São João de Meriti experiencing the lowest levels of robbery concentration (e.g., 25 per cent of robbery was concentrated in 1.5 -3.1 per cent of all micro-units) (see Table 2). These variations did not appear to relate to differences in the levels of robberies (as reported in Table 1) but instead appeared to be related to the population density of each city. Overall, each of the seven cities experienced robbery concentration levels that were within Weisburd's defined bandwidths, and in most cases were closer to the lower ends of the bandwidths indicating very high levels of crime concentration. The one exception to this was São João de Meriti which experienced crime concentration levels that were above Weisburd's bandwidths. The robbery crime concentration levels in each city were very similar in 2015 and 2016 even though the number of robberies had significantly increased during this period. For example, in Duque de Caxias, 25 per cent of all robberies were concentrated in 0.5 per cent of micro-units in the city in both 2015 and 2016 even though robbery had increased by 63 percent over this time.

$<$ Table 2 here>

Table 3 shows that $S$ Index measures for each city were greater than 0.8 , with the exception of São João de Meriti (S Index = 0.54), suggesting the spatial patterns of robberies in 2016 were very similar to the patterns of robberies observed in 2015 for at least six cities. ODI values were extremely low for each city, below 0.09 , with the exception of São João de Meriti, suggesting the crime increase in six of the seven cities took place in only a small number of areas. In each case the NCDI was less than 0.206 suggesting the crime increase 
was contained within a small number of areas, albeit with differences between the cities. In the areas with the lowest NCDI values - Duque de Caxias, São Gonçalo and Nova Iguaçu a very small number of areas alone contributed to an equivalent increase in robbery across each city and relatively few other areas experienced any increase at all. In the cities of Rio de Janeiro, Niteroi and Belford Roxo, whilst a very small number of areas contributed to an equivalent increase in robbery across each city, the increase in other areas (whilst still being relatively small) was greater than in the three other aforementioned cities. In São João de Meriti, while ODI and NCDI values were also relatively low, the results suggested the crime increase was more dispersed in this city than in the other six cities.

$<$ Table 3 here>

The S Index, ODI and NCDI results broadly corroborate with each other, showing that in areas where the patterns of robbery between 2015 and 2016 were very similar, the increase in crime appeared to be contained to a relatively small proportion of areas (e.g., Nova Iguaçu: S Index 0.90, ODI 0.048, NCDI 0.064). In areas where the S Index was lower the increase in crime appeared to have affected a relatively larger proportion of areas (e.g., São João de Meriti: S Index 0.54, ODI 0.233, NCDI 0.206). The CCDI adds to the spatial stability and the increase dispersion results by directly indicating if areas of high crime concentration are where increases in crime have been most experienced. The CCDI results for each city were less than 1 (see Table 3), indicating the robbery increases were mainly associated with areas of high crime concentration experiencing more of the increase than any other areas. In Duque de Caxias and Nova Iguaçu the CCDI values were particularly low ( 0.281 and 0.247 respectively) suggesting that in these two cities the crime increases were not a result of new areas emerging as crime hot spots but were very much due to areas 
of previous high crime concentration experiencing the highest increases in crime. In contrast, in the city of Rio de Janeiro, whilst the S Index, ODI and NCDI results indicated a stable robbery pattern with increases in crime being highly contained to a small number of areas, the CCDI value of 0.702 indicated the robbery increase was associated with many new areas emerging as crime hotspots alongside the increases experienced in areas of previous high crime concentration. In São João de Meriti, whilst the patterns of robbery during the period of crime increase were the least stable of the seven cities and the crime increase appeared to be more dispersed, a CCDI value of 0.382 would suggest the best option would be to focus resource targeting to areas of highest crime concentration.

The increases in robbery in the high crime concentration areas are further illustrated in Table 4, showing that in each city the average increase in the number of robberies in high crime concentration areas was greater than that for the areas identified as experiencing significant increases in crime using the S Index method and the EPAs method. For cities where the CCDI value was low (e.g., Nova Iguaçu), the difference was much greater in the average increase in crime per high crime concentration area than the increase in crime per area using the two other measures.

$<$ Table 4 here>

\section{Discussion}

The observation that crime concentrates in space is well documented, with Weisburd (2015) suggesting the law of crime concentration to be universally valid. To date, most of the studies that have examined crime concentration have used data from the United States and provided the basis for defining the precise bandwidths into which these observations of 
crime occur. An examination of robbery for seven cities in the state of Rio de Janeiro has shown that the law of crime concentration is very present, and in most cases crime concentration levels were towards the lower ends of the bandwidths defined by Weisburd (2015). These results suggest that crime may be more concentrated than average in Latin American urban contexts than in the western-industrialized cities that have been the main subject of crime concentration examination to date. Reasons for these differences in crime concentration levels require further examination, but are perhaps most associated with differences in population density, the volume of crime and the distribution of opportunity space - each of which is considered further below.

The high levels of crime concentration in cities within the state of Rio de Janeiro remained stable during a period of significant crime increase. For example, in Nova Iguaçu where there was a 77 per cent increase in robberies, the proportion of micro-places where 25 per cent of robberies were concentrated remained at 0.4 per cent between 2015 and 2016. These results suggest that the volume of crime may have less influence on crime concentration levels and run contrary to the suggestion from Lee et al (2017) that falls in crime in western industrialized cities explained reductions in crime concentration. For this argument to be valid, their hypothesis must work in both directions - during a period of crime increase, crime concentration also increases. This was not apparent in the current study, and hence suggests that rather than crime levels explaining differences in crime concentration levels, differences in population density factors and changes in opportunity space may be more valid reasons.

Whilst knowing that crime concentration levels did not change during a period of crime increase is useful, these results do not indicate if the areas of high crime concentration 
identified during a more recent period were the same high concentration areas identified in a previous period, and if these areas alone were responsible for the increases that had been experienced. The S Index results suggest there was very little shift in the spatial patterns in robbery during the period of crime increase. The differences in the $\mathrm{S}$ Index between the seven cities appeared to be positively related to the population density of each city rather than being related to differences in each city's robbery rate. This relationship is possibly due to a more geographically dispersed opportunity space for the commission of crime in areas of high population density (i.e., many areas exhibiting opportunities for crime), and hence the choice of area in which to commit crime may change more frequently over time. This then indicates it is changes in the opportunity space that is more likely to influence changes in crime concentration levels.

The S Index method also identified that a relatively small proportion of areas experienced significant increases in crime, with the results for ODI and NCDI measures also showing the increase in each city was mainly associated with increases in a small number of areas. Combined, these results suggest that robbery remained highly concentrated during a period of significant crime increase, patterns in the overall spatial distribution of robbery between 2015 and 2016 changed very little, and only a small number of areas were responsible for the increases in crime. These findings help to compound the argument that crime concentration at the micro-place level is likely to be related to the distribution of opportunity space. For instance, because the opportunity space for robbery commission has changed very little, the patterns of robbery have changed very little as well.

These results generated from the S Index and Dispersion Calculator do not, however, indicate whether the areas where high crime concentration was observed should be the 
places to target, or should other areas associated with the main crime increases be targeted. The CCDI offers a simple and practical measure for directly determining if during a period of crime increase, priority should be given to targeting high crime concentration areas or if other areas should also be targeted. In areas where the CCDI is less than 1, and in particular when it is close to zero, priority should be given to those areas of high crime concentration where the increases have been experienced, rather than just targeting those areas where crime has particularly increased. During a period of crime increase, if high crime concentration areas are where the increase has been most experienced, this suggests the opportunity space for the commission of crime is likely to be quite fixed. When the opportunity space is quite fixed this would also suggest that any targeted program to high crime concentration areas is less likely to experience geographic crime displacement effects because opportunities to commit crime are not present in other areas. If the CCDI is closer to 1 , crime displacement may be more likely because opportunities to commit crime are present in other areas. This suggests the CCDI could also be used to potentially predict when crime displacement is more likely to occur. These arguments also add further support to the reasoning that crime concentrates in some micro-places rather than others due to only certain places possessing the opportunities for crime to occur.

Opportunity for crime does not mean that a crime is certain, which means that the areas where crime does occur must possess other favorable conditions such as being easy for offenders to reach and where offenders are aware opportunities exist. This means that the places where opportunities for crime to occur are restricted further to the micro-places where these other favorable conditions must also be present, with these favorable conditions likely to be specific different for certain crime types (e.g., robbery from the person and house burglary), and overlapping for others (e.g., robbery from the person and theft from the 
person). Offenders may also adapt their criminal behavior over time, and new offenders will appear to replace those who were prolific before them. These new offenders may emerge from the same neighborhoods where former offenders operated from, or may emerge from new neighborhoods. This in turn suggests that it is a combination of favorable conditions consisting of opportunity space, offending site selection, and neighborhood factors that may explain why crime occurs in some micro-places and not in others, and why new high crime micro-places may emerge while others may persist over time.

For each city, approximately 7 per cent of grid cells were identified using the S Index and Dispersion Calculator methods to have experienced a significant increase in robberies $(\mathrm{p}=0.01)$ or had been identified as emerging problem areas (see Table 4$) .7$ per cent of any city is still a large area, and typically too large for any targeted resource deployment. Areas of high crime concentration were much smaller in coverage - five cities had high crime concentration areas that covered less than 1 per cent of the city area and two cities had high crime concentration areas that covered 1.5 and 3 per cent of their city area. This suggests that identifying high crime concentration areas may offer a better initial means of selecting areas to prioritize, and in the cases where the CCDI was less than 1, targeting resources to areas of high crime concentration would likely be of most benefit. Furthermore, each microplace unit could be ranked using the Dispersion Calculator results and additionally assist the prioritization of areas to target. Table 5 provides an illustration of this additional prioritization, using the example of Duque de Caxias. 60 cells were identified in Duque de Caxias as high crime concentration areas - these cells covered 0.5 per cent of the city area and accounted for 31 per cent of all robberies in 2016. The top ten high crime concentration areas that were ranked by the Dispersion Calculator as experiencing the highest increases in robbery covered an area of 0.08 per cent of the city and accounted for 6.2 per cent of all 
robberies. These ten highest ranked high crime concentration areas experienced a 142 per cent increase in robbery compared to the 116 per cent increase across all high crime concentration areas in the city, with these highest ranked cells each accounting for an average of 40 robberies in 2016. Furthermore, the robbery increase in just these ten cells was equivalent to a 7.6 per cent city-wide robbery increase. Targeting high crime concentration cells by the order of their Dispersion Calculator ranking can provide an effective additional means of prioritization, which when associated with a low CCDI value (of 0.281 in the case of Duque de Caxias) would suggest that crime displacement to new areas is unlikely.

$<$ Table 5 here>

The current study used grid cells to examine micro-place patterns of crime concentration. Whilst the use of grid cells was due to street segments not being available and their easier use in generating other statistical measures, these grid cells were judged to be slightly larger than the street segments we could have used (if available). Larger geographic units result in lower levels of crime concentration (Steenbeck and Weisburd, 2016), suggesting that the crime concentration levels in the study areas would have been even higher if street segments were used. In turn, this suggests CCDI values may have been slightly lower if street segments were used. The current study also focused on only examining patterns of robbery, mainly due to significant increases in this crime type, and the potential use of the research results for informing targeted police deployment in Rio de Janeiro. The focus on robberies has its limitations because it would be worthwhile to examine how other crime types may have increased alongside robbery and if so in the same concentrated manner. However, the focus on robbery helped to develop the theoretical arguments on favorable conditions, which 
may have been less likely if the research lacked this specificity. In addition, the current study only examined the dispersion of crime concentration between two data points (2015 and 2016). In situations where an increase has endured for a longer time period, further research could involve a longitudinal examination of the dispersion of crime concentration. Further research could also involve testing the impact of CCDI-driven priority setting through the randomized control of areas that receive targeted resources identified in accordance with CCDI results, and the theory testing of favorable conditions by examining which conditions have the greatest influence in generating low CCDI levels during periods of crime increase.

\section{Conclusion}

The observation that crime concentrates in space is well established, to the degree that Weisburd (2015) has suggested a universal law of crime concentration. To date, most studies of crime concentration have involved examining western industrialized cities, from which the bandwidths for the law of crime concentration have been defined. This study provides one of the first detailed, multi-city, crime-specific examinations of crime concentration patterns in a Latin American context. In the seven cities in the state of Rio de Janeiro, robberies were found to concentrate more than had typically been observed in other studies. These findings substantiate the general universal validity of Weisburd's (2015) law of crime concentration that a small number of places are responsible for a large proportion of crime.

Each of the seven cities in Rio de Janeiro experienced significant increases in robbery between 2015 and 2016. Over this period of crime increase, robbery remained highly concentrated, patterns in the overall spatial distribution of robbery changed very little, and only a small number of areas were responsible for the increases in crime. With the use of a crime concentration dispersion measure, it was possible to directly determine whether 
priority in any resource targeting should be given to those areas of high crime concentration where increases had been experienced, or if other areas associated with the crime increases should be targeted.

The findings from the current study point to the theoretical notion of 'favorable conditions', by suggesting that thinking in terms of opportunity space alone is not sufficient for understanding why certain micro-places experience high levels of crime, and that consideration should also be given to offending site selection and neighborhood factors for explaining crime concentration at micro-places. In additional practice terms, the results indicate that geographically-focused resource deployment initiatives, such as hot spot policing, could be of significant value in reducing robbery in Latin American urban contexts.

\section{References}

Andresen MA (2009) An area-based nonparametric spatial point pattern test: The test, its applications, and the future. Methodological Innovations 9:1-11.

Andresen MA and Malleson M (2011) Testing the stability of crime patterns: implications for theory and policy. Journal of Research in Crime and Delinquency 48:58-82

Bernasco W and Steenbeek W (2017) More places than crimes: implications for evaluating the law of crime concentration at place. Journal of Quantitative Criminology 33:3:451-467

Braga AA, Hureau DM and Papachristos AV (2010) The concentration and stability of gun violence at micro places in Boston, 1980-2008. Journal of Quantitative Criminology 26:3353 
Braga AA, Hureau DM and Papachristos AV (2011) The relevance of micro places to citywide robbery trends: a longitudinal analysis of robbery incidents at street corners and block faces in Boston. Journal of Research in Crime and Delinquency 48:7-32

Braga AA, Andresen MA and Lawton B (2017) The law of crime concentration at places: Editors' Introduction. Journal of Quantitative Criminology 33:3 421-426.

Braga AA and Weisburd D (2012) Policing problem places: crime hot spots and effective prevention. Oxford University Press: New York

Chainey SP and Ratcliffe JH (2005) GIS and Crime Mapping. Wiley: London

Chainey SP, Tompson L and Uhlig S (2008a) The utility of hotspot mapping for predicting spatial patterns of crime. Security Journal 21:1-2.

Curman AS, Andresen MA, and Brantingham PJ (2014) Crime and place: a longitudinal examination of street segment patterns in Vancouver, BC. Journal of Quantitative Criminology 31:1:127-147

Dammert L and Malone M (2006) Does It Take a Village? Policing Strategies and Fear of Crime in Latin America. Latin American Politics and Society 48:4:27-51 
Gill C, Wooditch A and Weisburd D (2017) Testing the 'law of crime concentration at place' in a suburban setting: implications for research and practice. Journal of Quantitative Criminology 33:421-426.

Groff ER, Weisburd D and Morris N (2008) Where the Action is at Places: Examining Spatio-Temporal Patterns of Juvenile Crime at Places Using Trajectory Analysis and GIS, in D Weisburd, W Bernasco and G Bruinsma (Eds.) Putting Crime in it's Place: Units of Analysis in Spatial Crime Research. New York, NY: Springer.

Guerry AM (1833) Essai sur la statistique morale de la France: precede d'un rapport a l'Academie de sciences. Paris: Chez Crochard.

Inter-American Development Bank (2016) Violent crime in Latin American cities. Discussion paper number IDB-DP-474. Washington, D.C.: IDB. Accessed on 4 October 2017 https://publications.iadb.org/handle/11319/7821

Jaitman L and Ajzenman N (2016) Crime concentration and hot spot dynamics in Latin America. Inter-American Development Bank: Washington, D.C.

Lee Y, Eck JE, O S and Martinez N (2017) How concentrated is crime at places? A systematic review from 1970 to 2015. Crime Science 6:6:1-16

Mejía D, Ortega D and Ortiz K (2015) Un análisis de la criminalidad urbana en Colombia. Documento de Trabajo CAF: Caracas, Venezuela 
de Melo SN, Matias LF, Andresen MA (2015) Crime concentrations and similarities in spatial crime patterns in a Brazilian context. Applied Geography 62: 314-324.

Mendes de Miranda, AP and Ferreira, M (2008) An analytical technique for addressing geographical referencing difficulties and monitoring crimes in Rio de Janeiro, Brazil, in S Chainey and L Tompson (Eds.) Crime Mapping Case Studies: Practice and Research. Chichester: Wiley.

Openshaw S (1984) The Modifiable Areal Unit Problem, Concepts and Techniques in Modern Geography 38. Norwich: Geobooks.

Pereira DVS, Mota CMM and Andresen MA (2016) The homicide drop in Recife, Brazil: a study of crime concentrations and spatial patterns. Homicide Studies 21:1:21-38

Ratcliffe JH (2004) Geocoding crime and a first estimate of a minimum acceptable hit rate. International Journal of Geographic Information Science 18:1:61-72

Ratcliffe JH (2010) The spatial dependency of crime increase dispersion. Security Journal 23:18-36.

Sherman LW, Gartin PR and Buerger ME (1989) Hot spots of predatory crime: routine activities and the criminology of place. Criminology 27:27-56 
Smith WR, Frazee SG and Davison EL (2000) Furthering the integration of routine activity and social disorganization theories: small units of analysis and the study of street robbery as a diffusion process. Criminology 38:2:489-524

Steenbeck W and Weisburd D (2016) Where the action is in crime? An examination of variability of crime across different spatial units in The Hague, 2001-2009. Journal of Quantitative Criminology 32:3:449-469

UNODC (2017) United Nations Office on Drugs and Crime Statistics Online https://data.unodc.org/ (Accessed 10 October 2017)

Weisburd D (2015) The law of crime concentration and the criminology of place. Criminology 53:133-157.

Weisburd D, Bushway S, Lum C and Yang S (2004) Trajectories of crime at places: a longitudinal study of street segments in the city of Seattle. Criminology 42:283-322

Weisburd D, Morris N and Groff ER (2009). Hot Spots of Juvenile Crime: A Longitudinal Study of Street Segments in Seattle, Washington. Journal of Quantitative Criminology 25(4): 443-467

Weisburd D, Groff ER and Yang S (2012) The criminology of place: street segments and our understanding of the crime problem. Oxford University Press: Oxford, U.K. 
Chainey and Monteiro (2016) The dispersion of crime concentration during a period of crime increase. Security Journal

Weisburd D and Telep CW (2014). Hot spots policing: What we know and what we need to know. Journal of Contemporary Criminal Justice 30:2:200-220 


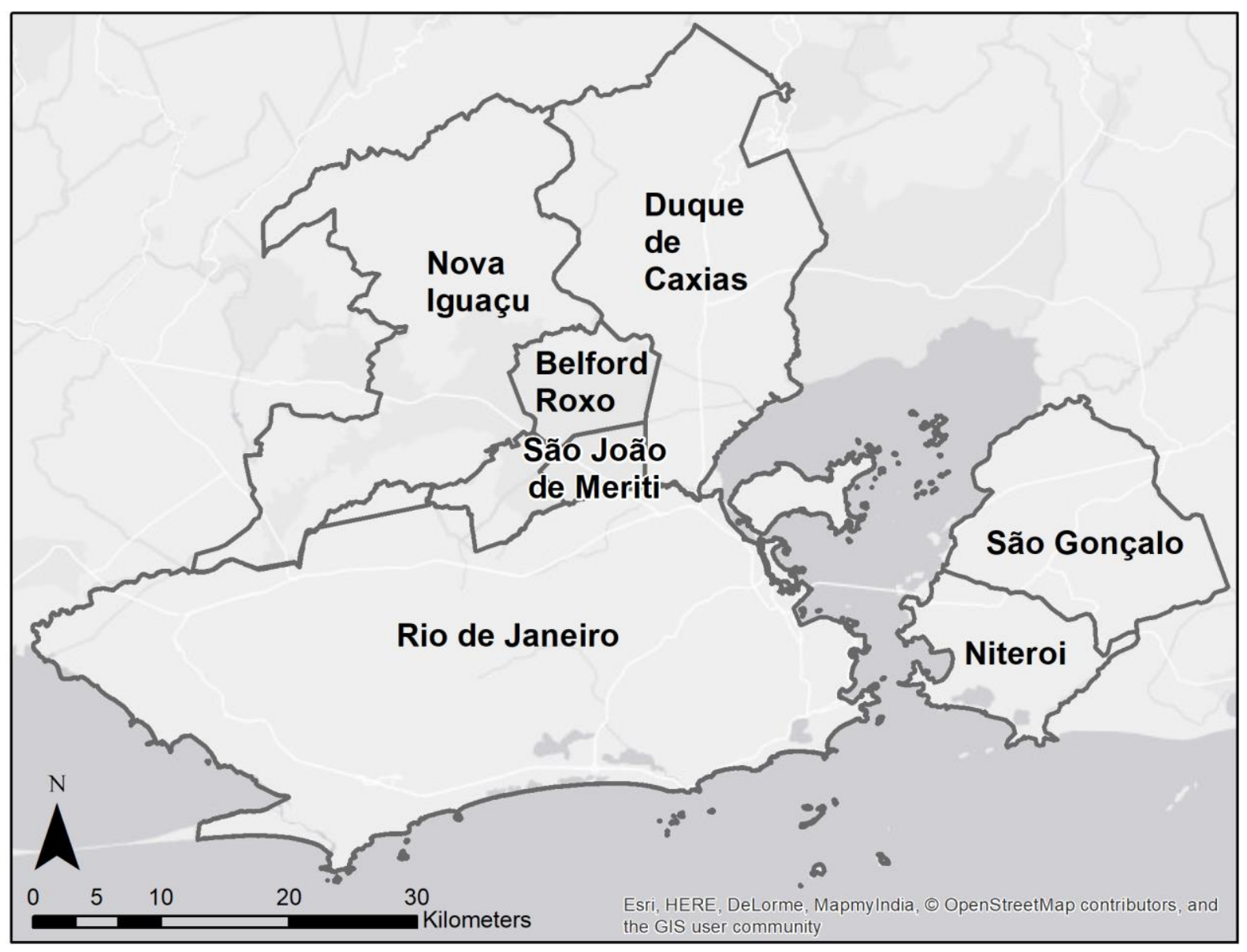

Figure 1. The seven largest cities of the state of Rio de Janeiro 
Table 1. Population, population density, robbery levels and change in robbery

\begin{tabular}{|l|c|c|c|c|c|}
\hline City & Population & $\begin{array}{c}\text { Population } \\
\text { density (pop } \\
\text { per km²) }\end{array}$ & $\begin{array}{c}\text { n robbery } \\
2016\end{array}$ & $\begin{array}{c}\text { Robbery rate } \\
2016(\mathrm{per} \\
100000 \mathrm{pop})\end{array}$ & $\begin{array}{c}\text { Change } \\
2015 / 16\end{array}$ \\
\hline Rio de Janeiro & 6498837 & 5306 & 55149 & 849 & $+25 \%$ \\
\hline Duque de Caxias & 1044058 & 2248 & 7938 & 760 & $+63 \%$ \\
\hline São Gonçalo & 886917 & 3575 & 12357 & 1393 & $+82 \%$ \\
\hline Nova Iguaçu & 797435 & 1521 & 8310 & 1042 & $+69 \%$ \\
\hline Niteroi & 497883 & 3845 & 4629 & 930 & $+37 \%$ \\
\hline São João de Meriti & 460541 & 13219 & 5293 & 1149 & $+77 \%$ \\
\hline Belford Roxo & 434474 & 5441 & 2681 & 617 & $+72 \%$ \\
\hline
\end{tabular}


Table 2. Robbery crime concentration levels in 2015 and 2016

\begin{tabular}{|l|r|r|r|r|}
\hline City & $\begin{array}{r}\text { Percentage of } \\
\text { cells within } \\
\text { which 25 per } \\
\text { cent of robberies } \\
\text { occurred in } \\
2015\end{array}$ & $\begin{array}{r}\text { Percentage of } \\
\text { cells within } \\
\text { which 50 per } \\
\text { cent of robberies } \\
\text { occurred in } \\
2015\end{array}$ & $\begin{array}{r}\text { Percentage of } \\
\text { cells within } \\
\text { which 25 per } \\
\text { cent of robberies } \\
\text { occurred in } \\
2016\end{array}$ & $\begin{array}{r}\text { Percentage of } \\
\text { cells within } \\
\text { which 50 per } \\
\text { cent of robberies } \\
\text { occurred in } \\
2016\end{array}$ \\
\hline Rio de Janeiro & $0.8 \%$ & $3.3 \%$ & $0.8 \%$ & $3.5 \%$ \\
\hline Duque de Caxias & $0.5 \%$ & $2.3 \%$ & $0.5 \%$ & $2.4 \%$ \\
\hline São Gonçalo & $0.8 \%$ & $3.2 \%$ & $1.0 \%$ & $3.7 \%$ \\
\hline Nova Iguaçu & $0.4 \%$ & $1.9 \%$ & $0.4 \%$ & $2.2 \%$ \\
\hline Niteroi & $0.9 \%$ & $3.1 \%$ & $0.8 \%$ & $3.1 \%$ \\
\hline $\begin{array}{l}\text { São João de } \\
\text { Meriti }\end{array}$ & $3.1 \%$ & $9.9 \%$ & $3.3 \%$ & $10.5 \%$ \\
\hline Belford Roxo & $1.5 \%$ & $4.3 \%$ & $1.7 \%$ & $4.9 \%$ \\
\hline
\end{tabular}


Table 3. S Index, Dispersion Calculator and Crime Concentration Dispersion Index values

\begin{tabular}{|l|l|l|l|l|}
\hline City & S Index & ODI & NCDI & CCDI \\
\hline Rio de Janeiro & 0.80 & 0.034 & 0.134 & 0.702 \\
\hline Duque de Caxias & 0.86 & 0.048 & 0.082 & 0.281 \\
\hline São Gonçalo & 0.82 & 0.084 & 0.092 & 0.390 \\
\hline Nova Iguaçu & 0.90 & 0.048 & 0.064 & 0.247 \\
\hline Niteroi & 0.84 & 0.037 & 0.106 & 0.425 \\
\hline São João de Meriti & 0.54 & 0.233 & 0.206 & 0.382 \\
\hline Belford Roxo & 0.82 & 0.084 & 0.106 & 0.489 \\
\hline
\end{tabular}


Table 4. Average increases in robbery per grid cell for S Index, Dispersion Calculator and crime concentration measures

\begin{tabular}{|c|c|r|r|r|r|r|}
\hline City & \multicolumn{2}{|l|}{$\begin{array}{l}\text { S Index - cells identified } \\
\text { with statistically } \\
\text { significant increase }\end{array}$} & \multicolumn{2}{l|}{\begin{tabular}{l}
\multicolumn{2}{l|}{ Dispersion Calculator - } \\
cells identified as EPAs
\end{tabular}} & \multicolumn{2}{l}{$\begin{array}{l}\text { Crime concentration - } \\
\text { cells identified as CCAs }\end{array}$} \\
\cline { 2 - 7 } & $\begin{array}{r}\text { proportion } \\
\text { of all cells) }\end{array}$ & $\begin{array}{r}\text { Average } \\
\text { increase in } \\
\text { robberies } \\
\text { per cell }\end{array}$ & $\begin{array}{r}\text { n (proportion } \\
\text { of all cells) }\end{array}$ & $\begin{array}{r}\text { Average } \\
\text { increase in } \\
\text { robberies } \\
\text { per cell }\end{array}$ & $\begin{array}{r}\text { Average } \\
\text { proportion } \\
\text { of all cells }\end{array}$ & $\begin{array}{r}\text { rncrease in } \\
\text { robberies } \\
\text { per cell }\end{array}$ \\
\hline $\begin{array}{c}\text { Rio de } \\
\text { Janeiro }\end{array}$ & $\begin{array}{c}2425 \\
(5.8 \%)\end{array}$ & 5 & $1427(3.4 \%)$ & 7 & $350(0.8 \%)$ & 8 \\
\hline $\begin{array}{c}\text { Duque de } \\
\text { Caxias }\end{array}$ & $442(3.7 \%)$ & 4 & $577(4.8 \%)$ & 4 & $60(0.5 \%)$ & 11 \\
\hline $\begin{array}{c}\text { São } \\
\text { Gonçalo }\end{array}$ & $581(5.9 \%)$ & 4 & $833(8.4 \%)$ & 4 & $78(0.8 \%)$ & 8 \\
\hline $\begin{array}{c}\text { Nova } \\
\text { Iguaçu }\end{array}$ & $415(3.0 \%)$ & 4 & $663(4.8 \%)$ & 4 & $59(0.4 \%)$ & 11 \\
\hline Niteroi & $220(4.1 \%)$ & 5 & $195(3.7 \%)$ & 6 & $47(0.9 \%)$ & 10 \\
\hline $\begin{array}{c}\text { São João } \\
\text { de Meriti }\end{array}$ & 258 & 5 & $387(23.3 \%)$ & 5 & $51(3.1 \%)$ & 10 \\
\hline $\begin{array}{c}\text { Belford } \\
\text { Roxo }\end{array}$ & $202(5.2 \%)$ & 4 & $327(8.4 \%)$ & 3 & $58(1.5 \%)$ & 5 \\
\hline
\end{tabular}


Table 5. Robbery levels in Duque de Caxias for the top ten CC EPAs, all CCAs and all other areas

\begin{tabular}{|l|l|l|l|l|l|}
\hline $\begin{array}{l}\text { City: Duque de } \\
\text { Caxias }\end{array}$ & $\mathrm{n}$ of cells (\%) & $\begin{array}{l}\mathrm{n} \text { robbery } \\
2016(\%)\end{array}$ & $\begin{array}{l}\text { Average } \\
\text { robberies } \\
\text { per cell } \\
(2016)\end{array}$ & $\begin{array}{l}\text { Change in } \\
\text { robberies } \\
2015-2016 \\
(\%)\end{array}$ & $\begin{array}{l}\text { Contribution } \\
\text { to city-wide } \\
\text { increase of } \\
63 \%\end{array}$ \\
\hline $\begin{array}{l}\text { Top 10 CC } \\
\text { EPAs }\end{array}$ & $10(0.08 \%)$ & $400(6.2 \%)$ & 40 & $235(+142 \%)$ & $7.6 \%$ \\
\hline All CCAs & $60(0.5 \%)$ & $1985(31 \%)$ & 33 & $1067(+116 \%)$ & $30 \%$ \\
\hline All other areas & $11917(99.5 \%)$ & $4421(69 \%)$ & 0.4 & $1400(+46 \%)$ & $25.6 \%$ \\
\hline
\end{tabular}

